\title{
Middle Miocene climate of southwestern Anatolia from multiple botanical proxies
}

\author{
Johannes Martin Bouchal ${ }^{1,2}$, Tuncay Hüseyin Güner ${ }^{3,1}$, and Thomas Denk ${ }^{1}$ \\ ${ }^{1}$ Department of Palaeobiology, Swedish Museum of Natural History, 10405 Stockholm, Sweden \\ ${ }^{2}$ Department of Palaeontology, University of Vienna, 1090 Vienna, Austria \\ ${ }^{3}$ Faculty of Forestry, Department of Forest Botany, Istanbul University Cerrahpaşa, 34473 Bahçeköy, Istanbul, Turkey
}

Correspondence: Johannes Martin Bouchal (johannes.bouchal@nrm.se) and Thomas Denk (thomas.denk@nrm.se)

Received: 25 June 2018 - Discussion started: 9 July 2018

Revised: 13 September 2018 - Accepted: 24 September 2018 - Published: 17 October 2018

\begin{abstract}
The middle Miocene climate transition (MMCT) was a phase of global cooling possibly linked to decreasing levels of atmospheric $\mathrm{CO}_{2}$. The MMCT coincided with the European Mammal Faunal Zone MN6. From this time, important biogeographic links between Anatolia and eastern Africa include the hominid Kenyapithecus. Vertebrate fossils suggested mixed open and forested landscapes under (sub)tropical seasonal climates for Anatolia. Here, we infer the palaeoclimate during the MMCT and the succeeding cooling phase for a middle Miocene (14.8-13.2 Ma) intramontane basin in southwestern Anatolia using three palaeobotanical proxies: (i) Köppen signatures based on the nearest living-relative principle; (ii) leaf physiognomy analysed with the Climate Leaf Analysis Multivariate Program (CLAMP); (iii) genus-level biogeographic affinities of fossil flora with modern regions. The three proxies reject tropical and hot subtropical climates for the MMCT of southwestern Anatolia and instead infer mild warm temperate $C$ climates. Köppen signatures reject summer-dry Cs climates but cannot discriminate between fully humid $\mathrm{Cf}$ and winter-dry $\mathrm{Cw}$; CLAMP reconstructs $\mathrm{Cf}$ climate based on the low X3.wet/X3.dry ratio. Additionally, we assess whether the palaeobotanical record resolves transitions from the warm Miocene Climatic Optimum (MCO, 16.8-14.7 Ma) to the MMCT (14.713.9 Ma), and a more pronounced cooling at 13.9-13.8 Ma, as reconstructed from benthic stable isotope data. For southwestern Anatolia, we find that arboreal taxa predominate in MCO flora (MN5), whereas in MMCT flora (MN6) abundances of arboreal and non-arboreal elements strongly fluctuate, indicating higher structural complexity of the vegetation. Our data show a distinct pollen zone between MN6 and
\end{abstract}

MN7 +8 dominated by herbaceous taxa. The boundary between MN6 and MN7 + 8, roughly corresponding to a first abrupt cooling at 13.9-13.8 Ma, might be associated with this herb-rich pollen zone.

\section{Introduction}

The middle Miocene (15.97-11.63 Ma, ICS-chart 2017/02, Cohen, 2013) is characterized by a warm phase lasting until ca. $15 \mathrm{Ma}$ that was followed by a gradual cooling and the restoration of a major Antarctic ice sheet and the first northern hemispheric glaciations (Holbourn et al., 2014). It has been suggested that the final closure of the Mediterranean gateway connecting the Mediterranean with the Indian Ocean and the resulting changes in ocean circulation might have been one of the reasons for the final expansion of the East Antarctic Ice Sheet around 14.8 Ma (Flower and Kennett, 1995). During the middle Miocene climate transition (MMCT) at 14.7 to $13.8 \mathrm{Ma}$, a drop in sea surface temperatures of $6-7^{\circ} \mathrm{C}$ occurred (Shevenell et al., 2004). At the same time, different proxies to reconstruct atmospheric $\mathrm{CO}_{2}$ levels for the Miocene Climatic Optimum (MCO), MMCT, and the succeeding more pronounced cooling do not concur (Beerling and Royer, 2011). Specifically, stable isotope data from phytoplankton infer stable $\mathrm{CO}_{2}$ levels for the Neogene, with minor fluctuations (MCO, 227-327 ppm; MMCT, 265300 ppm; see Table S1 of Beerling and Royer, 2011), while stomata densities from fossil leaves suggest a pronounced drop in $\mathrm{CO}_{2}$ after the MCO (see Table $\mathrm{S} 1$ of Beerling and Royer, 2011). 
The European Mammal Faunal Zone MN6 (14.8-13.8 Ma; Neubauer et al., 2015) coincides with the MMCT. From this period world-famous vertebrate faunas are known from western Anatolia (e.g. Andrews and Tobien, 1977; Mayda et al., 2015) including the hominoids Griphopithecus alpani in Çandır and Paşalar and Kenyapithecus kizili in Paşalar (Stringer and Andrews, 2011). Geraads et al. (2003) investigated the depositional environment and large mammal fauna of Çandır close to Ankara and inferred open landscapes for this locality. Bernor et al. (1979, p. 86) analysed the community structure of Turkish and European middle Miocene fauna and suggested that "faunas adapted to woodland conditions were present ... at localities such as Paşalar and Yeni Eskihisar [MN7+8]" while the "Çandır fauna has a community structure more suggestive of closed woodland conditions". This interpretation is the exact opposite of that by Geraads et al. (2003). Recent investigations using carnivore guild structure suggest a "mixed environment between tropical forest and open savannah landscapes" for Çandır and Paşalar (Mayda et al., 2015). Strömberg et al. (2007) investigated phytoliths (plant silica bodies) from early to late Miocene deposits of Turkey and suggested that open, grassdominated habitats had become common in Turkey and adjacent areas by the early Miocene (ca. 20 Ma). In contrast, Kayseri-Özer (2017) using "integrated plant record" (IPR) analysis (Kovar-Eder et al., 2008) suggested that various forest types covered most of western and Central Anatolia during the middle Miocene (broad-leaved evergreen and mixed mesophytic forests and ecotones between these forests).

Here we use a large dataset from recently published macrofossils and pollen, spores, and cysts from a well-dated middle Miocene basin in western Anatolia to infer palaeoclimate and palaeoenvironments using three palaeobotanical proxies: climate affinity of modern analogues ("nearest living relatives"; taxon-based approach), leaf physiognomy (ataxonomic), and biogeographic affiliation of plant communities (also taxon-based). The following research questions are addressed. How do the three approaches resolve local climate conditions of Anatolia during a phase of global cooling, ca. 15-13 million years ago? Do different proxies agree on climate inference? Where do modern climates occur that correspond to middle Miocene climates of western Anatolia? Can the palaeobotanical record resolve transitions between MCO, MMCT, and the succeeding more pronounced cooling during the middle Miocene?

\section{Material and methods}

\subsection{Geological setting}

The Yatağan Basin is a southeast-trending graben $(50 \mathrm{~km}$ long, $15 \mathrm{~km}$ wide) in the province of Muğla, southwestern Turkey (Fig. 1). The Neogene basin fill is up to $600 \mathrm{~m}$ thick and divided into the Eskihisar Formation (early to middle Miocene), the Yatağan Formation (late Miocene to

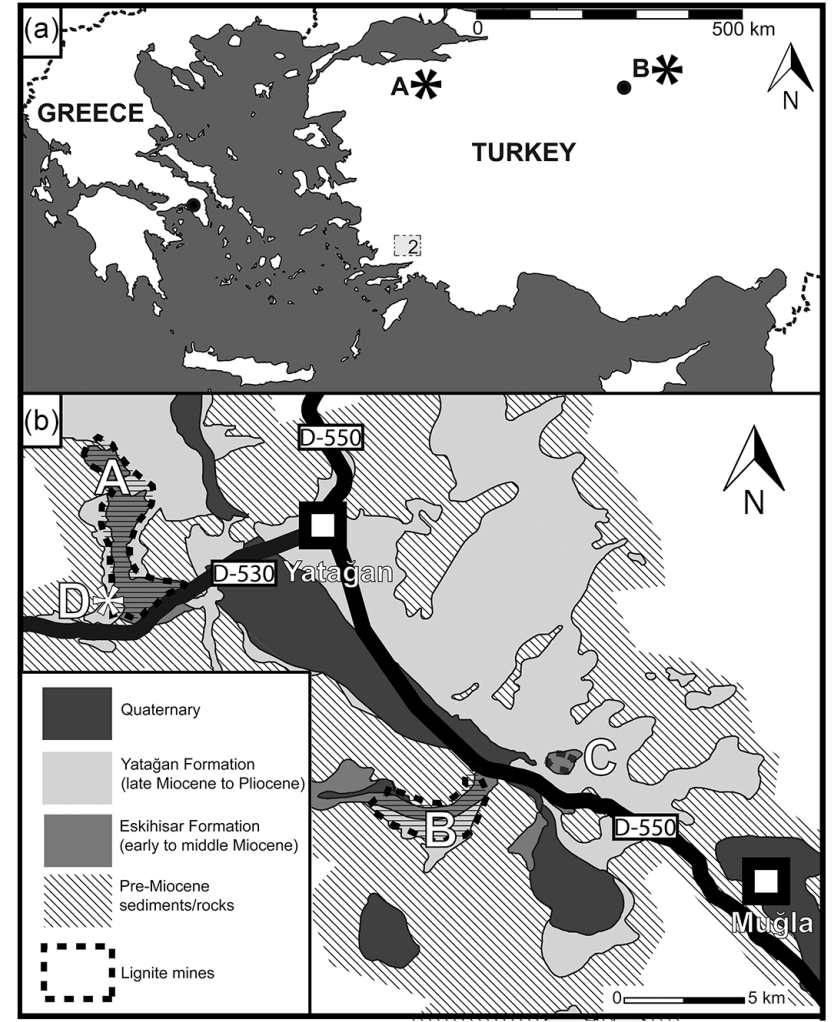

Figure 1. Geographic and regional geologic setting of the Yatağan Basin. (a) Map showing the geographical position of the Yatağan Basin (2) and the MN6 vertebrate fossil localities (*) Paşalar (A) and Çandir (B). (b) Simplified regional geological map of the Yatağan Basin based on Becker-Platen (1970) and Atalay (1980); lignite mines Eskihisar (A), Tınaz (B), Salihpaşalar (C); vertebrate fossil locality (*) Yeni Eskihisar MN7/8 (D).

early Pliocene), and the Milet Formation (middle to late Pliocene; Alçiçek, 2010). The Eskihisar Formation comprises the Turgut Member (reddened alluvial-fan deposits followed by fluviatile deposits and lignites) and the Sekköy Member (fossiliferous limnic marls and limestones); all economically exploited lignite seams of the Yatağan Basin are confined to the transition zone of these two members (Atalay, 1980; Becker-Platen, 1970).

For the present study, we investigated the palaeobotanical content (pollen and plant macrofossils) of the upper Turgut and the Sekköy members exposed at the lignite mines of Eskihisar, Salihpaşalar, and Tinaz (Fig. 1b). The age of the investigated sediments is well constrained by mammal fossils (Eskihisar lignite gallery locality, MN6, Gomphotherium angustidens Cuvier 1817, Percrocuta miocenica Pavlov et Thenius 1965 - Bouchal et al., 2017; Yeni Eskihisar vertebrate locality, MN 7/8 - The NOW Community, 2018) and by radiometric dates from the upper Sekköy Member (13.2 Ma \pm 0.35 , Becker-Platen et al., 1977). Hence, the investigated pollen zones (PZs) 1, 2, and 2/3 and the Yeni 
Eskihisar pollen assemblage represent the Neogene mammal zones MN6 and MN7 + 8, 14.8-13.2 Ma (Neubauer et al., 2015). The layers from which most of the leaf fossils originate correspond to $\mathrm{PZ} 2$. A $\sim 20 \mathrm{~m}$ section comprised of limestone and clayey limestone between PZ 2/3 and the Yeni Eskihisar assemblage is barren of palynological content (Fig. 2).

\subsection{Plant material}

The investigated plant material comprises roughly 1800 macrofossils (mainly leaf fossils) collected between 2010 and 2017. Macrofossils represent 77 taxa, of which 5 belong to gymnosperms and 72 to angiosperms. Pollen, spores, and cysts from five pollen zones (Fig. 2) represent 182 taxa, of which 1 is a fungus, 9 are algae, 17 are moss or fern ally spores, 15 are gymnosperms, and 140 are angiosperms (Supplement S1; for taxonomic descriptions of the plant taxa see Yavuz-Iş1k et al., 2011; Bouchal et al., 2016, 2017; Bouchal, 2018; Güner et al., 2017).

\subsection{Köppen signatures}

Fossil taxa that are resolved to genus or sectional level were represented by extant members of the genera and sections as modern analogues. First, for accepted taxa (IPNI, http: //www.ipni.org/index.html, last access: 13 September 2018; most recent regional floras and monographs), the distribution ranges were determined. Then, 26 Köppen-Geiger climate types (see Table 3 for detailed explanation of Köppen-Geiger climate types, and Kottek et al., 2006; Peel et al., 2007; Rubel et al., 2017; Global_1986-2010_KG_5m.kmz) were mapped onto modern distribution ranges using Google Earth to establish "Köppen signatures" (Denk et al., 2013) for each modern analogue. The representation of different climate types was first scored for each species within a genus as present (1)/absent (0). To summarize preferences for climate types of all modern analogues, we used an implicit weighting scheme to discriminate between modern analogues that are highly decisive (climatically constrained) and those that can be found in many climate zones. The sum of each modern species' Köppen signature is always 1 . For example, Tilia chingiana is present in two Köppen-Geiger climate types, $\mathrm{Cfa}$ and $\mathrm{Cfb}$, which count as 0.5 for each type, while Tilia americana is present in 10 Köppen-Geiger climate types (As, Aw, Cfa, $\mathrm{Cfb}$, Dfa, Dfb, Cwa, Cwb, BSk, BWh), all counting as 0.1. The Köppen signature of a genus or section, the modern analogue of a fossil taxon, is the sum of its species' Köppen signatures for each climate type divided by the total number of scored species for this genus. By this, the percentage representation of each Köppen-Geiger climate type was determined for a genus/section. In the case of Tilia, the distribution ranges of 26 species resulted in the following genus Köppen signature: Cfa, $22.1 \%$, Cfb, $14.7 \%$, Cwa, $19.9 \%$, Cwb, $9.1 \%$, Dfb, $5.7 \%$ for the five most common climate

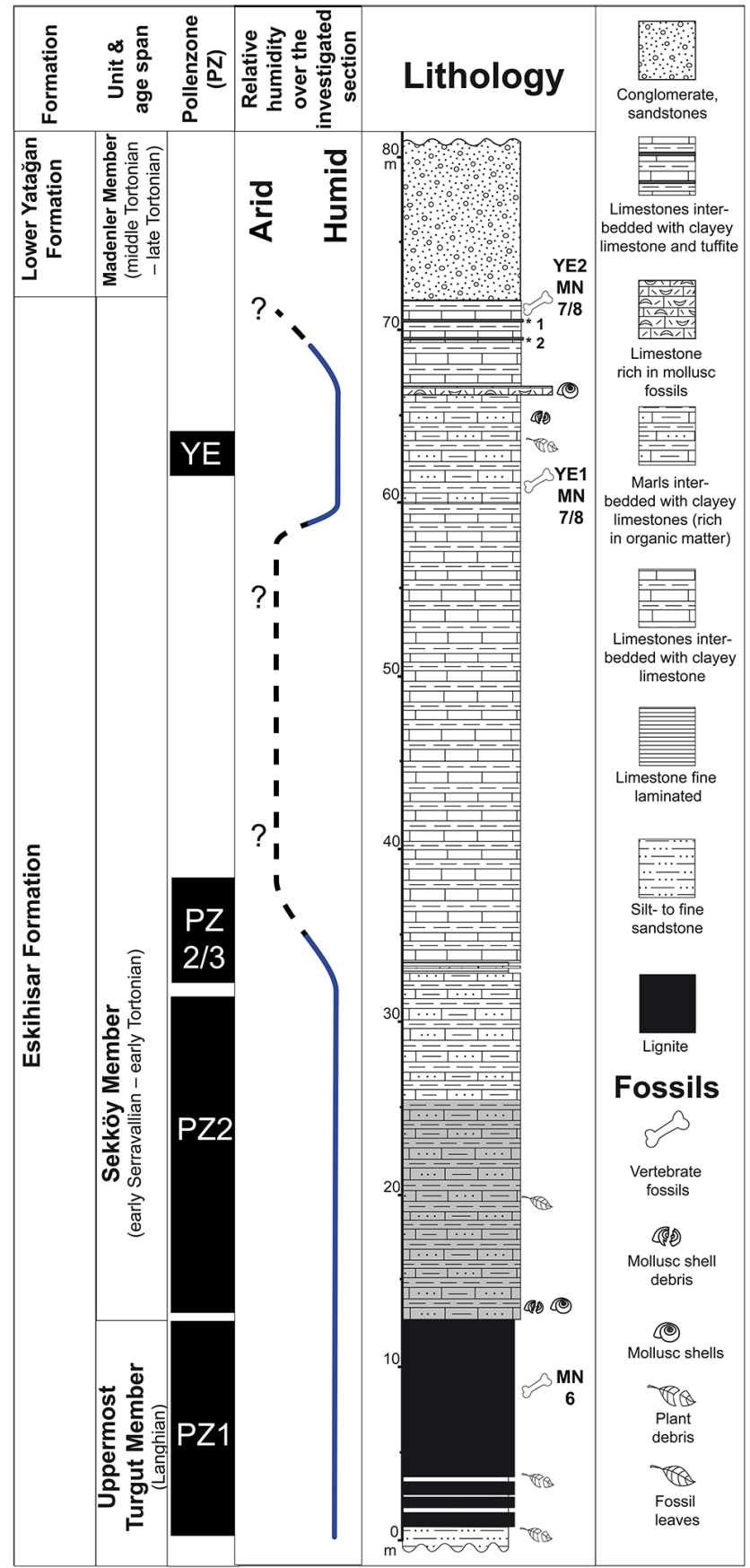

Figure 2. Generalized lithostratigraphic column for the Eskihisar lignite mine and pollen zones (PZs). The main part of the investigated plant macrofossils originates from ca. $10 \mathrm{~m}$ thick deposits overlying the exploited lignite seams (part of the section highlighted in grey corresponding to PZ 2). Yeni Eskihisar 2 (YE2) and Yeni Eskihisar 1 (YE1) vertebrate fossil localities (Becker-Platen et al., 1977). Radiometrically dated tuff layers $(*): 1^{*}-11.2 \pm 0.2 \mathrm{Ma} ; 2^{*}$ - 13.2 \pm 0.35 Ma (Becker-Platen et al., 1977). 


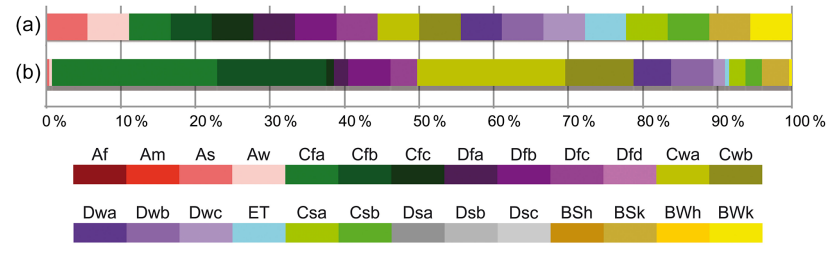

Figure 3. Köppen signal for genus Tilia extracted from 26 extant species. (a) Köppen-Geiger climates in which Tilia is present. (b) Combined Köppen signature of all 26 extant Tilia species. Diagrams based on extracted data from Supplement S2.

types. Figure 3a shows all climate types realized in genus Tilia; Fig. $3 \mathrm{~b}$ shows that the genus occurs predominantly in $\mathrm{Cf}$ and $\mathrm{Cw}$ Köppen-Geiger climate types and that tropical and desert climates are nearly absent (see Supplement S3 for genus-level scoring of Köppen-Geiger climate types for all plant taxa encountered in the Yatağan basin fossil assemblages).

For taxa that are resolved to family-level only, mainly pollen taxa of herbaceous and a few woody angiosperm groups, the distributions of extant members of the family were combined into a general family distribution range and the corresponding Köppen-Geiger climate types determined.

Genus-level Köppen-Geiger signals were used to account for possible niche evolution within lineages or species groups of a genus. For example, modern species of Quercus section Ilex are typical members of sclerophyllous, evergreen Mediterranean forest and shrubland vegetation thriving under a Cs (summer-dry warm temperate) climate in western Eurasia and to the south of the eastern Hindu Kush and Karakorum ranges but also occur in humid, mesophytic forests from Afghanistan to East Asia (Cf and $\mathrm{Cw}$ climates). To account for this climate niche variability, all species of section Ilex were scored for the general Köppen signature of section Ilex. Hence, the entire section was used as modern analogue, the nearest living relative (NLR), for several fossil species of Quercus section Ilex.

\subsection{CLAMP}

We inferred quantitative palaeoclimate parameters for the three Yatağan Basin floras using the Climate Leaf Analysis Multivariate Program (CLAMP) (Yang et al., 2011). CLAMP makes use of the relationship between leaf physiognomy of dicotyledonous flowering plants and climate and, hence, is a non-taxonomic approach to palaeoclimate inference (Spicer, 2008). CLAMP calibrates the numerical relations between leaf physiognomy of woody dicots and meteorological parameters in modern terrestrial environments. With this calibration, past climatic data can be determined from leaf fossil assemblages if the sampling of the fossil assemblage represents the characteristics of the living source vegetation well (http://clamp.ibcas.ac.cn, last access: 13 Septem- ber 2018). Modern and fossil leaf physiognomic data are positioned in multidimensional physiognomic space using canonical correspondence analysis (CANOCO; Ter Braak, 1986). CANOCO orders vegetation sites based on a set of attributes (leaf physiognomic characters).

For modern sites, climate variables are known from longterm observations of climate stations or from high-resolution gridded climate data (New et al., 1999, 2002; Spicer et al., 2009). Vectors for each of the measured climate variables can be positioned in physiognomic space and calibrated. Palaeoclimate variables can then be quantified by scoring a fossil assemblage in the same manner as for the modern vegetation and positioning the fossil site in physiognomic space (http://clamp.ibcas.ac.cn, last access: 13 September 2018).

For the present study, 36 different leaf characters (including leaf shape and size, apex shape, base shape, and leaf margin characteristics) were scored for 61,63 , and 14 dicotyledonous leaf morphotypes from three localities: Tinaz, Eskihisar, and Salihpaşalar (see Supplement S3 for scoring of morphotypes), following the CLAMP protocols (http:// clamp.ibcas.ac.cn, last access: 13 September 2018). At genus level, the flora of the Yatağan Basin shows the highest similarity with Eurasian extant woody angiosperms (Table 1), thus the PhysgAsial Calibration file dataset of CLAMP was used to position the fossil data.

\subsection{Genus-level biogeographic affinities}

For all fossil taxa determined to genus level, the present distribution was tabulated indicating the presence or absence of a genus in western Eurasia, East Asia, eastern North America, western North America, or Africa (Table 1).

\section{Results}

\subsection{Climate inference from Köppen signatures (Fig. 5, Supplement S4, S5)}

For the fossil plant assemblages warm temperate to temperate $\mathrm{C}$ and D climates accounted for almost $80 \%$ of the realized Köppen-Geiger climate types of all taxa in a fossil plant assemblage (using genus-level NLR). The sum of Cf, Df, Cw, and Dw climates amounted to $60 \%-70 \%$ in all assemblages (highest scores in macrofossil assemblages).

Overall, the best represented Köppen-Geiger climate types when using genus-level NLR were Cfa (warm temperate, fully humid, hot summer), followed by $\mathrm{Cfb}$ (warm temperate, fully humid, warm summer; e.g. Fig. 4g, h), Cwa (warm temperate, winter-dry, hot summer), and Cwb (warm temperate, winter-dry, warm summer). Summer-dry Cs climates were represented by $9 \%-13 \%$ and arid (generally dry) B climates by $6 \%-11 \%$ (e.g. Fig. 4a, b, Table 3, Supplement S4). Tropical (equatorial) climates (A) are represented by $9 \%-11 \%$ in older assemblages and $7 \%-8 \%$ in the two youngest assemblages (PZ 2/3 and Yeni Eskihisar). 
Table 1. Genus-level biogeographic affinities of fossil taxa of the Yatağan Basin flora.

\begin{tabular}{|c|c|c|c|c|c|c|c|c|}
\hline Latest occurrence W Eurasia & Fossil taxon (genus level) & $w_{E U R}^{f}$ & EA & eNA & wNA & SA & $\mathrm{AF}$ & AUS \\
\hline & Ephedra & + & + & + & + & + & + & \\
\hline Pliocene $^{\mathrm{a}}$ & Glyptostrobus & ? & + & ? & ? & $?$ & $?$ & ? \\
\hline Taxodium type, $<0.1 \mathrm{Ma}^{\mathrm{a}}$ & Taxodium & ? & $?$ & + & + & & & \\
\hline \multirow{4}{*}{$0.5-0.4 \mathrm{Ma}^{\mathrm{a}}$} & Cathaya & & + & & & & & \\
\hline & Cedrus & + & + & & & & & \\
\hline & Picea & + & + & + & + & & & \\
\hline & Pinus & + & + & + & + & & & \\
\hline \multirow[t]{2}{*}{$0.4-0.3 \mathrm{Ma}^{\mathrm{a}}$} & Tsuga & $?$ & + & + & + & & & \\
\hline & Acer & + & + & + & + & & & \\
\hline \multirow[t]{2}{*}{ Late Pliocene ${ }^{b}$} & Ailanthus & & + & & & & & \\
\hline & Alnus & + & + & + & + & + & ? & ? \\
\hline \multirow[t]{5}{*}{ No data } & Apios & & + & + & & & & \\
\hline & Betula & + & + & + & + & $?$ & ? & ? \\
\hline & Buxus & + & + & + & + & + & + & \\
\hline & Buxus (balearica type) & + & + & & & & & \\
\hline & Carpinus & + & + & + & ? & $?$ & ? & ? \\
\hline \multirow[t]{2}{*}{$<0.1 \mathrm{Ma}^{\mathrm{a}}$} & Carya & $?$ & + & + & $?$ & $?$ & $?$ & $?$ \\
\hline & Castanea & + & + & + & $?$ & $?$ & $?$ & $?$ \\
\hline \multirow[t]{4}{*}{ Pliocene $^{c}$} & Cedrelospermum ${ }^{\mathrm{g}}$ & + & + & & + & & & \\
\hline & Celtis & + & + & + & + & + & + & + \\
\hline & Centranthus & + & + & ? & ? & $?$ & & ? \\
\hline & Corylus & + & + & + & + & $?$ & ? & ? \\
\hline \multirow{4}{*}{ Pleistocene $^{\mathrm{d}}$} & Decodon & $?$ & $?$ & + & $?$ & $?$ & $?$ & $?$ \\
\hline & Drosera & + & + & + & + & + & + & + \\
\hline & Erica & + & & & & & + & \\
\hline & Erodium & + & + & + & + & + & + & + \\
\hline \multirow[t]{10}{*}{$0.6 \mathrm{Ma}^{\mathrm{a}}$} & Eucommia & $?$ & + & $?$ & $?$ & $?$ & $?$ & $?$ \\
\hline & Euphorbia & + & + & + & + & + & + & + \\
\hline & Fagus & + & + & + & $?$ & $?$ & $?$ & $?$ \\
\hline & Fraxinus & + & + & + & + & $?$ & $?$ & $?$ \\
\hline & Ilex & + & + & + & + & + & + & + \\
\hline & Juglans & + & + & + & + & + & $?$ & $?$ \\
\hline & Linum & + & + & + & + & + & + & + \\
\hline & Liquidambar & + & + & + & ? & $?$ & $?$ & $?$ \\
\hline & Lonicera & + & + & + & + & $?$ & & $?$ \\
\hline & Ludwigia & + & + & + & + & + & + & + \\
\hline \multirow[t]{6}{*}{ Pliocene $^{\mathrm{d}}$} & Mahonia & $?$ & + & $?$ & $?$ & $?$ & $?$ & $?$ \\
\hline & Nitraria & + & + & ? & ? & $?$ & + & + \\
\hline & Ostrya & + & + & + & ? & $?$ & $?$ & ? \\
\hline & Parrotia & + & $?$ & ? & ? & $?$ & ? & ? \\
\hline & Persicaria & + & + & + & + & + & & \\
\hline & Phragmites & + & + & + & + & + & + & + \\
\hline No data & Picrasma & & + & + & + & + & & \\
\hline \multirow[t]{9}{*}{ Pleistocene $\mathrm{e}^{\mathrm{e}}$} & Podocarpium & + & + & $?$ & $?$ & $?$ & $?$ & $?$ \\
\hline & Polygonum & + & + & + & + & & & \\
\hline & Populus & + & + & + & + & & & \\
\hline & Pterocarya & + & + & $?$ & $?$ & $?$ & $?$ & $?$ \\
\hline & Quercus & + & + & + & + & + & & \\
\hline & Rumex & + & + & + & + & + & + & + \\
\hline & Salix & + & + & + & + & + & & \\
\hline & Scabiosa & + & & & & & + & \\
\hline & Smilax & + & + & + & + & + & + & + \\
\hline \multirow[t]{9}{*}{$14.8-13.8 \mathrm{Ma}$} & Smilax (havanensis group) & & & + & & + & & \\
\hline & Sorbus & + & + & + & + & & & \\
\hline & Sparganium & + & + & + & + & & & + \\
\hline & Tilia & + & + & + & + & $?$ & $?$ & ? \\
\hline & Typha & + & + & + & + & + & + & + \\
\hline & Ulmus & + & + & + & + & & & \\
\hline & Viburnum & + & + & + & + & + & & \\
\hline & Zelkova & + & + & $?$ & $?$ & $?$ & $?$ & $?$ \\
\hline & No. of genera/region & $\begin{array}{c}48 \\
w_{E U R}^{f}\end{array}$ & $\begin{array}{c}54 \\
\text { EA }\end{array}$ & $\begin{array}{c}44 \\
\text { eNA }\end{array}$ & $\begin{array}{c}36 \\
\text { wNA }\end{array}$ & $\begin{array}{l}21 \\
\text { SA }\end{array}$ & $\begin{array}{r}16 \\
\mathrm{AF}\end{array}$ & $\begin{array}{c}13 \\
\text { AUS }\end{array}$ \\
\hline
\end{tabular}

\footnotetext{
${ }^{\mathrm{a}}$ Magri et al. (2017). ${ }^{\mathrm{b}}$ Corbett and Manchester (2004). ${ }^{\mathrm{c}}$ Jia et al. (2015). ${ }^{\mathrm{d}}$ Martinetto (2001). ${ }^{\mathrm{e}}$ Wang et al. (2007). ${ }^{\mathrm{f}}$ Including northern Africa. g Extinct genus. wEUR: western Eurasia; EA: East Asia; eNA: eastern North America; wNA: western North America; SA: South America; AF: Africa (excluding northern Africa); AUS: Australia.
} 

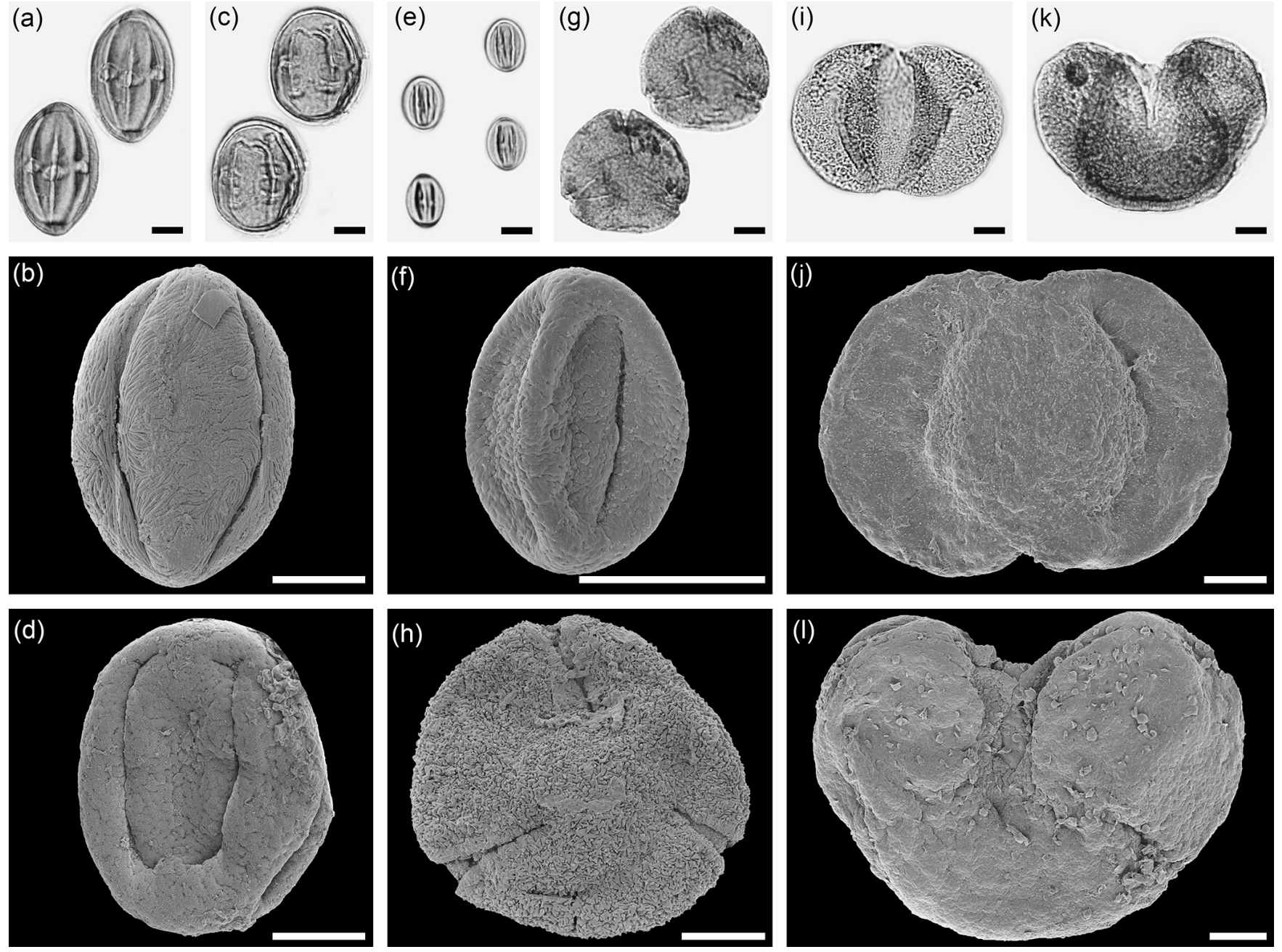

Figure 4. Selected pollen grains light microscopy (LM) (a, c, e, g, i, k) and scanning electron microscopy (SEM) (b, d, f, h, j, l) micrographs of the same fossil pollen grain of the Eskihisar (E), Tınaz (T), and Salihpaşalar (S) sections. (a-b) Nitraria sp., EV (E, S153567). (c-d). Sapotaceae gen. indet., EV (T, S143604). (e-f) Decodon sp., EV (S, S153635). (g-h) Fagus sp., PV (T, S143621). (i-j) Cathaya sp., (i) PV, (j) PRV (S, S153632). (k-l) Cedrus sp., EV (E, S153590). EV: equatorial view; PV: polar view; PRV: proximal view. Scale bar: $10 \mu$ m (a-l).

Of 1555 modern species used to inform the Köppen signatures of the NLRs for the fossil taxa, 119 show marginal range extensions into Af climate, 168 into Am (heavy monsoon), 85 into As, and 295 into Aw (Supplement S2). Taxa extending into tropical climates are mainly species of $\mathrm{Pi}$ nus, Celtis, Smilax, and Viburnum, Quercus sections Quercus and Lobatae, Juglandaceae subfamily Engelhardioideae, Oleaceae, and Sapotaceae (Fig. 4c, d). The exclusion of Köppen-Geiger climate signals extracted from cosmopolitan and/or gymnospermous taxa (Fig. 4i-1) did not change the general trends (Supplement S5).

\subsection{CLAMP}

Sixty-three morphotypes were scored for Eskihisar (Fig. 6; see Supplement S3 for score sheets and other reconstructed climate parameters). The inferred values for mean annual temperature (MAT) were $(11.2-) 12.6(-14)^{\circ} \mathrm{C}$, for coldestmonth mean temperature (CMMT) $(0.3-) 2.3(-4.4)^{\circ} \mathrm{C}$, and for the three wettest months (X3.wet) (410-) $666(-936) \mathrm{mm}$ and for the three driest months (X3.dry) (148-) 204 (262) $\mathrm{mm}$. The ratio X3.wet/X3.dry was between 2.9 and 3.6. For Tinaz, the reconstructed MAT was (12.3-) 13.8 (15.2 ${ }^{\circ} \mathrm{C}$, CMMT (1.5-) $3.6(-5.6)^{\circ} \mathrm{C}$, X3.wet (420-) 700 $(-980) \mathrm{mm}$, and X3.dry $(146-) 205(-260) \mathrm{mm}$. The ratio X3.wet/X3.dry was between 2.9 and 3.8. Values for Salihpaşalar are not considered here as they are based on too small a set of morphotypes (see Supplement S3).

\subsection{Genus-level biogeography}

The genus-level biogeographic analysis of the four Yatağan Basin floras ranging in age from 14.8 to $13.2 \mathrm{Ma}$ (MN6 into MN7 + 8; Table 1) shows that closest biogeographic relation- 


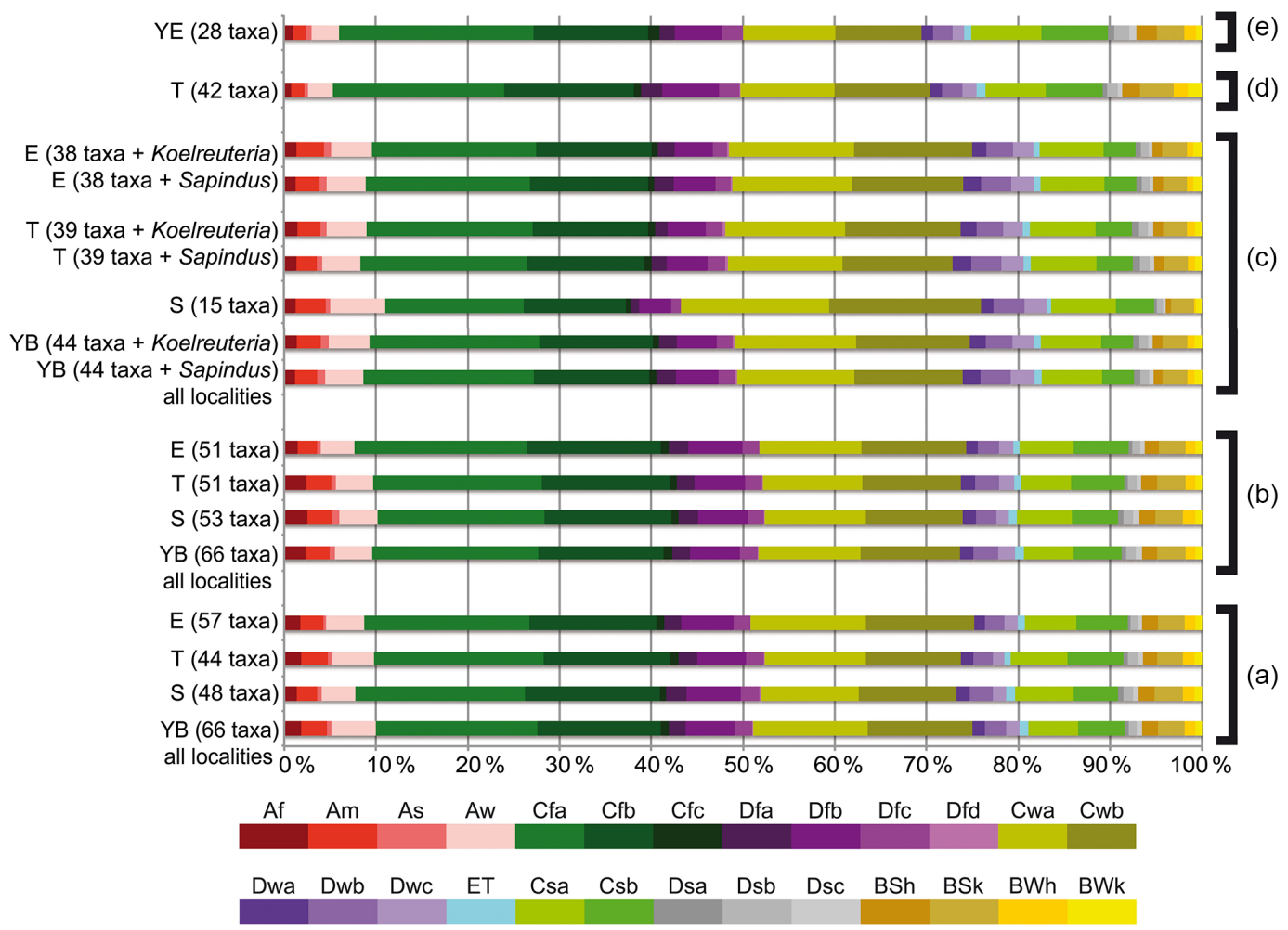

Figure 5. Köppen signals for the Yatağan Basin flora. (a) Pollen zone (PZ) 1 (MN6; 14.95-13.9 Ma) of the Eskihisar (E), T1naz (T), and Salihpaşalar (S) localities and the combined signal of all present taxa from PZ 1 of the three Yatağan Basin localities (YB). (b) PZ 2 (MN6) of E, T, S, YB. (c) Macrofossil (MF) assemblages (same level as PZ 2) of E, T, S. (d) PZ 2/3 of T (younger than Yeni Eskihisar vertebrate locality). (e) Yeni Eskihisar vertebrate locality pollen assemblage (MN7/8, younger than radiometric age 13.2 Ma). Diagrams based on extracted data from Supplement S2.

ships are with the modern East Asian flora (54 of 59 taxa shared with East Asia); 48 and 44 genera are shared with the modern western Eurasian and eastern North American flora, respectively. Among modern tropical floras, the closest relationships are with South America (21), followed by Africa (16) and northern-northeastern Australia (13). Most taxa extending to tropical regions are cosmopolitan (e.g. Euphorbia, Drosera, Phragmites) and hence of little discriminative power. This is also true for higher taxa such as Polygalaceae and Valerianoideae. The fossil species Smilax miohavanensis belongs to a subtropical-tropical clade of extant species (Denk et al., 2015) and is the only member of this group in Eurasia; it has its last occurrence in the middle Miocene flora of the Yatağan Basin. Overall, the dominating biogeographic signal is a northern hemispheric one.

\subsection{Changes in ratios of arboreal to non-arboreal pollen}

Ratios of arboreal pollen (AP) to non-arboreal pollen (NAP) change considerably among and within pollen zones of the Yatağan Basin assemblages (Table 2, Supplement S6). Pollen zone 1 (main lignite seam) consistently has high percentages of AP (94\%-70\%). In contrast, AP percentage values fluc- tuate throughout pollen zone 2, with values from 89 to 29 . Pollen zone 2-3, only covered in the Tinaz section, records AP percentages of 50 to 19 . Above, the MN7 +8 assemblage of Yeni Eskihisar shows again a higher proportion of arboreal taxa $(67 \%)$. Similarly, from the vertebrate locality Çatakbağyaka (revised age MN7 $+8,12 \mathrm{~km}$ south of the Yatağan Basin), AP percentages range from ca. $50 \%$ to ca. $80 \%$ (Jiménez-Moreno, 2005; Mayda et al., 2016; Bouchal et al., 2017; Aiglstorfer et al., 2018).

We used the threshold $(\mathrm{AP} / \mathrm{NAP}=3.85)$ proposed by Favre et al. (2008) to separate between tree- and herbprevalent environments. This ratio translates into AP percentages of close to $80 \%$ to predict reliably tree-prevalent landscapes. As can be seen in Supplement S6, pollen zones 1 and 2 are largely dominated by forested environments. In the upper part of PZ2 (Tinaz, Eskihisar), PZ2/3, and PZ3 (Tinaz) herb-prevalent landscapes are inferred. However, it is noteworthy, that although NAP taxa are more abundant in these pollen zones, AP taxa continue to have fairly high percentages as well (Bouchal et al., 2016, 2017). For example, $\mathrm{Fa}$ gus and Quercus deciduous and evergreen type are still above the threshold values indicative of local tree presence (Lisitsyna et al., 2011). Hence, the opening of the vegetation in 


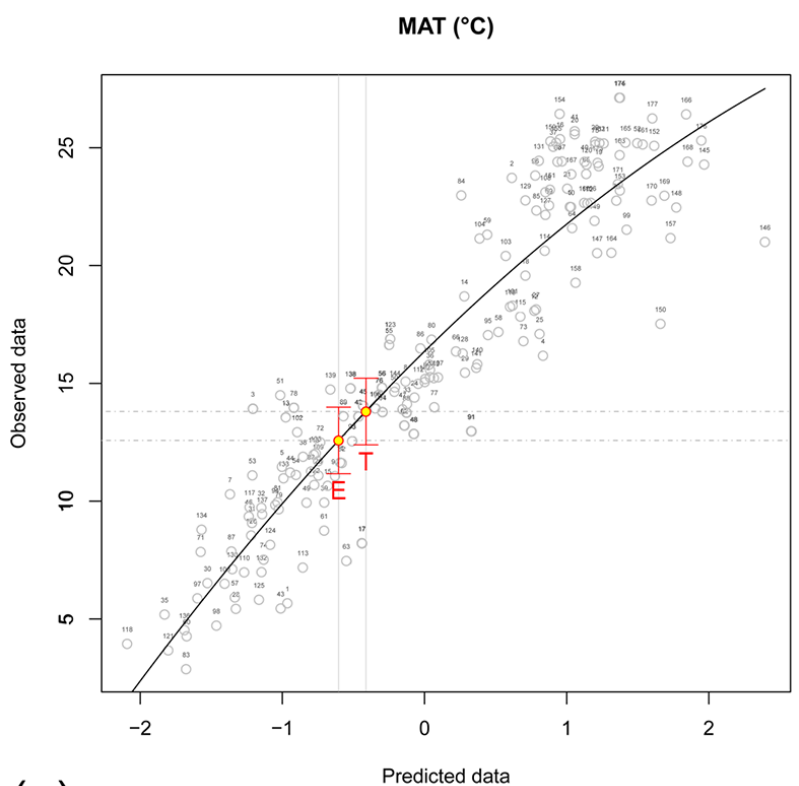

(a)

Predicted data

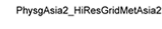

X3.WET (cm)
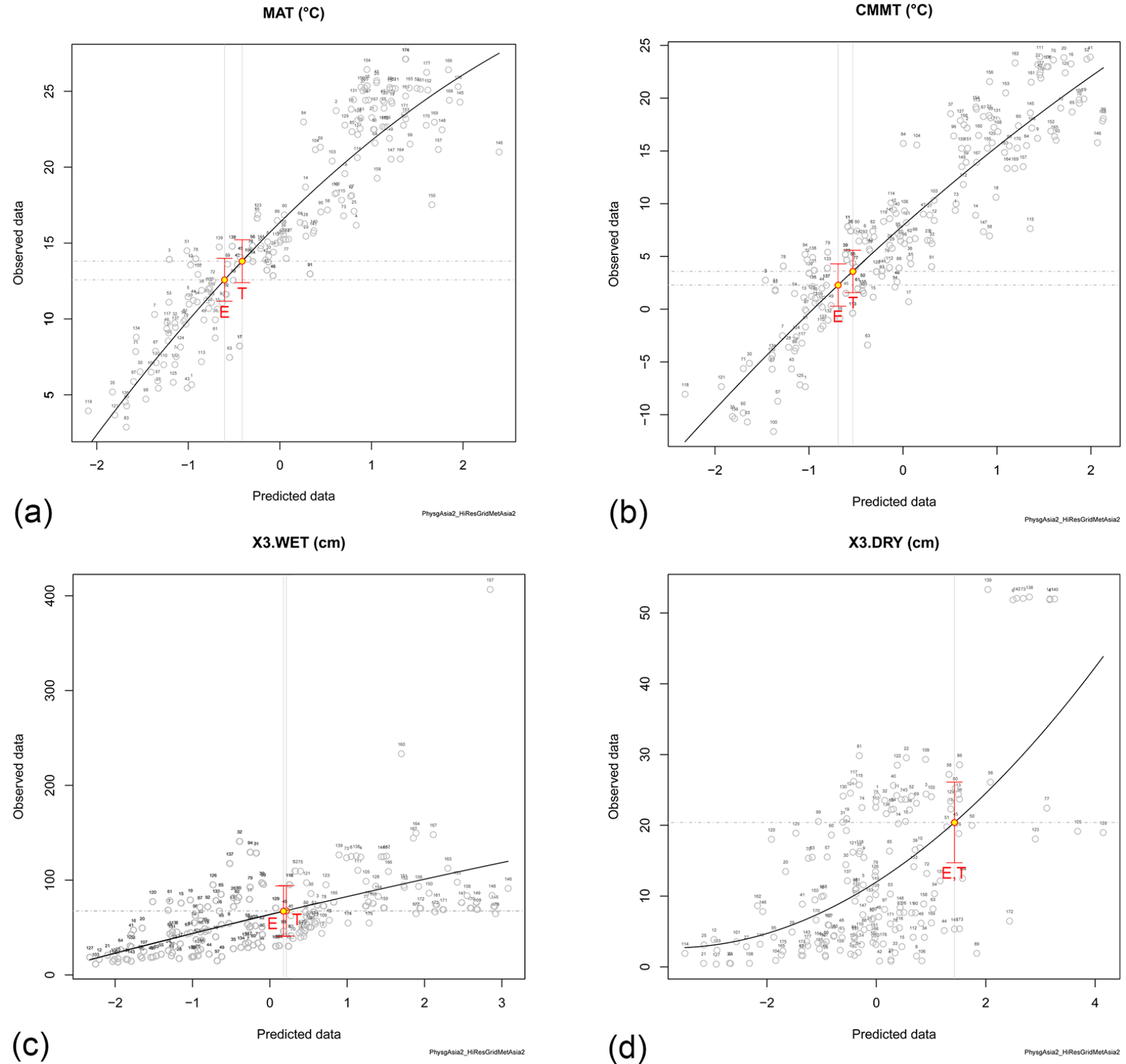

Figure 6. CLAMP climate inference for the macrofossil assemblage of (E) Eskihisar and (T) Tinaz (same level as PZ 2). (a) Mean annual temperature (MAT). (b) Coldest-month mean temperature (CMMT). (c) Precipitation of the 3 wettest months. (d) Precipitation of the 3 driest months.

the upper parts of PZ2 and in PZ2/3 and PZ3 may actually represent a coexistence of forest and open vegetation.

\section{Discussion}

\subsection{Climate inference using Köppen signatures and CLAMP}

Using Köppen signatures, we made a semi-quantitative reconstruction of the palaeoclimate of the Yatağan Basin during the middle Miocene. All Köppen signatures used here rely on the nearest living-relative principle (Denk et al., 
Table 2. Arboreal to non-arboreal pollen ratios in southwestern Anatolia across the MCO, MMCT, and subsequent cooling phase.

\begin{tabular}{|c|c|c|c|}
\hline Pollen zone & $\mathbf{A P}$ & NAP & \\
\hline Hüssamlar & 90.0 & 10.0 & $16.8 \mathrm{Ma}$ \\
\hline Kultak & 90.0 & 10.0 & MN5 \\
\hline Karacaağaç & 96.0 & 4.0 & \\
\hline \multirow[t]{7}{*}{ Tınaz PZ1 } & 89.6 & 10.4 & $14.8 \mathrm{Ma}$ \\
\hline & 96.8 & 3.2 & \multirow{6}{*}{ MN6 } \\
\hline & 0.0 & 0.0 & \\
\hline & 0.0 & 0.0 & \\
\hline & 78.8 & 21.2 & \\
\hline & 89.9 & 10.2 & \\
\hline & 0.0 & 0.0 & \\
\hline \multirow[t]{7}{*}{ Tınaz PZ2 } & 60.5 & 39.5 & \\
\hline & 93.6 & 6.4 & \\
\hline & 75.7 & 24.4 & \\
\hline & 91.4 & 8.6 & \\
\hline & 38.6 & 61.4 & \\
\hline & 52.6 & 47.4 & \\
\hline & 0.0 & 0.0 & $13.9 \mathrm{Ma}$ \\
\hline \multirow[t]{3}{*}{ Tınaz PZ2-3 } & 29.0 & 71.0 & \multirow{3}{*}{$\begin{array}{c}\text { (?)MN7+8 } \\
* \\
\text { MN7+8 }\end{array}$} \\
\hline & 0.0 & 0.0 & \\
\hline & 64.1 & 35.9 & \\
\hline Yeni Eskihisar & 67.0 & 33.0 & $13.2 \mathrm{Ma}$ \\
\hline
\end{tabular}

* Perhaps linked with the 13.9-13.8 Ma cooling event (Holbourn et al., 2014). AP: arboreal pollen (angiosperms).

NAP: non-arboreal pollen (angiosperms).

Wavy line: profiles separated by tens of metres of sediment barren of pollen.

Red to blue indicates change from warmer to cooler climate.

2013). Such approaches are prone to error because niche evolution may have occurred in lineages; the morphologically NLRs of fossil taxa, a species or group of morphologically similar species, may have different niches, and the shift is difficult to quantify (Ackerly, 2004; Grimm and Potts, 2016; Denk et al., 2017). Hence, we decided against applying quantitative NLR methods and determined Köppen signatures for fossil taxa using information from all extant species of a genus used as NLR to avoid bias from undetected niche shifts.

It is important to keep climatic niche shift in mind when using NLR based approaches to palaeoclimate inference and interpreting their results (Grimm and Potts, 2016; Denk et al., 2017). In our dataset of 1555 modern species, 295 also occur in tropical Aw climates. Most of them belong to clades (monophyletic sections, genera, families) that occur in a wide range of climate types (e.g. Amaranthaceae, Celtis, white and red oaks). Others, such as Engelhardia are usually interpreted as tropical-subtropical evergreen elements (Kvaček, 2007) based on the distribution range of the extant genera of the comprising subfamily, the Engelhardoideae. However, Engelhardia of the western Eurasian Cenozoic belongs to its own (extinct) section or genus Palaeocarya (Kvaček, 2007) with a stratigraphic range from the Eocene to the Pliocene.
Table 3. Description of Köppen-Geiger climate symbols and defining criteria (Kottek et al., 2006; Peel et al., 2007). MAP: mean annual precipitation; MAT: mean annual temperature; $T_{\text {hot }}$ : temperature of the hottest month; $T_{\text {cold }}$ : temperature of the coldest month; $T_{\text {mon10 }}$ : number of months where the temperature is above $10^{\circ} \mathrm{C}$; $P_{\mathrm{dry}}$ : precipitation of the driest month; $P_{\text {sdry }}$ : precipitation of the driest month in summer; $P_{\mathrm{wdry}}$ : precipitation of the driest month in winter; $P_{\text {swet }}$ : precipitation of the wettest month in summer; $P_{\text {wwet }}$ : precipitation of the wettest month in winter; $P_{\text {threshold }}$ : varies according to the following rules - if $70 \%$ of MAP occurs in winter, then $P_{\text {threshold }}=2 \times$ MAT; if $70 \%$ of MAP occurs in summer, then $P_{\text {threshold }}=2 \times \mathrm{MAT}+28^{\circ} \mathrm{C}$; otherwise $P_{\text {threshold }}=2 \times \mathrm{MAT}+14$. Summer (winter) is defined as the warmer (cooler) 6-month period of October-March and April-September.

\begin{tabular}{|c|c|c|c|}
\hline 1 st & 2nd & $3 \mathrm{rd}$ & Description and criteria \\
\hline \multirow[t]{5}{*}{ A } & & & Equatorial/tropical $\left(T_{\text {cold }} \geq 18^{\circ} \mathrm{C}\right)$ \\
\hline & $\mathrm{f}$ & & Rainforest, fully humid ( $\left.P_{\text {dry }} \geq 60 \mathrm{~mm}\right)$ \\
\hline & $\mathrm{m}$ & & Monsoonal (not Af \& $\left.P_{\text {dry }} \geq 100-\mathrm{MAP} / 25\right)$ \\
\hline & $\mathrm{s}$ & & $\begin{array}{l}\text { Savannah with dry summer } \quad\left(P_{\text {sdry }}<\right. \\
60 \mathrm{~mm})\end{array}$ \\
\hline & $\mathrm{w}$ & & Savannah with dry winter $\left(P_{\text {wdry }}<60 \mathrm{~mm}\right)$ \\
\hline \multirow[t]{5}{*}{ B } & & & Arid $\left(\right.$ MAP $\left.<10 \times P_{\text {threshold }}\right)$ \\
\hline & $\mathrm{W}$ & & Desert $\left(\right.$ MAP $\left.<5 \times P_{\text {threshold }}\right)$ \\
\hline & $\mathrm{S}$ & & Steppe (MAP $\left.\geq 5 \times P_{\text {threshold }}\right)$ \\
\hline & & $\mathrm{h}$ & Hot arid $\left(\mathrm{MAT} \geq 18^{\circ} \mathrm{C}\right)$ \\
\hline & & $\mathrm{k}$ & Cold arid $\left(\mathrm{MAT}<18^{\circ} \mathrm{C}\right)$ \\
\hline $\mathrm{C}$ & & & $\begin{array}{l}\text { Warm temperate/temperate }\left(T_{\text {hot }}>10^{\circ} \mathrm{C}\right. \\
\left.\& 0^{\circ} \mathrm{C}<T_{\text {cold }}<18^{\circ} \mathrm{C}\right)\end{array}$ \\
\hline \multirow[t]{8}{*}{$\mathrm{D}$} & & & Snow $/$ cold $\left(T_{\text {hot }}>10^{\circ} \mathrm{C} \& T_{\text {cold }} \leq 0^{\circ} \mathrm{C}\right)$ \\
\hline & $\mathrm{s}$ & & $\begin{array}{l}\text { Summer dry } \quad\left(P_{\text {sdry }}<40 \quad \& \quad P_{\text {sdry }}<\right. \\
\left.P_{\text {wwet }} / 3\right)\end{array}$ \\
\hline & $\mathrm{w}$ & & Winter dry $\left(P_{\mathrm{wdry}}<P_{\text {swet }} / 10\right)$ \\
\hline & f & & $\begin{array}{l}\text { Fully humid/without a dry season (not s or } \\
\text { w) }\end{array}$ \\
\hline & & $\mathrm{a}$ & Hot summer $\left(T_{\text {hot }} \geq 22^{\circ} \mathrm{C}\right)$ \\
\hline & & $\mathrm{b}$ & Warm summer $\left(\right.$ not a $\left.\& 1 \leq T_{\operatorname{mon} 10}<4\right)$ \\
\hline & & $\mathrm{c}$ & $\begin{array}{l}\text { Cool/cold summer (not a or b \& } T_{\operatorname{mon} 10} \geq \\
\text { 4) }\end{array}$ \\
\hline & & $\mathrm{d}$ & $\begin{array}{l}\text { Extremely continental/very cold winter } \\
\text { (not a or b \& } T_{\text {cold }}<-38^{\circ} \mathrm{C} \text { ) }\end{array}$ \\
\hline \multirow[t]{3}{*}{$\mathrm{E}$} & & & Polar $\left(T_{\text {hot }}<10^{\circ} \mathrm{C}\right)$ \\
\hline & $\mathrm{T}$ & & Polar tundra $\left(T_{\text {hot }}>0{ }^{\circ} \mathrm{C}\right)$ \\
\hline & $\mathrm{F}$ & & Polar frost $\left(T_{\text {hot }} \leq 0^{\circ} \mathrm{C}\right)$ \\
\hline
\end{tabular}

Pollen, foliage, and reproductive structures of fossil material clearly belong to the subfamily Engelhardioideae but cannot be assigned to just a single modern genus Engelhardia (tropical southeast Asia). Instead, the fossil taxon is a mosaic taxon having characteristics of both American and Asian members of the subfamily. Kvaček (2007) noted that the fossil genus/subgenus flourished in subtropical climates during the Eocene but in distinctly temperate climates with coldest-month mean temperatures close to the freezing point 
in the Neogene, in stark contrast to the surviving four, likely relict genera of the Engelhardioideae. Hence, this extinct lineage of Engelhardioideae is not well represented by a single genus or the combination of all extant genera and their constituent species. Similarly, representatives of Smilax havanensis and allied species are part of a New World clade with most species occurring in tropical climates. However, the single Old World member of the clade, the fossil species S. miohavanensis, is known from early to middle Miocene strata of Anatolia and central Europe (Denk et al., 2015). This fossil species formed part of plant assemblages that rule out tropical climates. In this case, inferring palaeoclimate from extant distribution data will inevitably only produce noise in the climatic signal.

Overall, the most common Köppen-Geiger climate types of NLR taxa of the Yatağan flora were warm temperate C types, and among $\mathrm{C}$ types fully humid $\mathrm{Cf}$ climates were better represented than more seasonal $\mathrm{Cw}$ and $\mathrm{Cs}$ types (Fig. 5; Supplement S4). Cs types played only a minor role; however, there was no clear preference of $\mathrm{Cf}$ over $\mathrm{Cw}$ climates in the representation of Köppen-Geiger climate types. Removing azonal taxa or taxa commonly associated with higher elevations (conifers) did not affect the general signal.

In contrast, CLAMP is not based on NLR and hence not potentially biased by taxonomic error. Its combination with the Köppen signature analysis provides a powerful tool for climate inference and to discern between seasonal $\mathrm{Cw}$ (winter dry) and Cs (summer dry) and fully humid Cf climates. Specifically, the ratio of the wettest and the driest month clearly distinguishes strongly seasonal summer rain (monsoon) climates $(\mathrm{Cw}$; precipitation wettest month $>10 \times$ precipitation driest month, $P_{\text {wdry }}<P_{\text {swet }} / 10$; Peel et al., 2007) from weakly seasonal, fully humid climates (Cf; precipitation wettest month $\ll 10 \times$ precipitation driest month). Precipitation values for X3.wet and X3.dry inferred by CLAMP and the ratio between these ranges being between 2.9 and 3.8 thus largely rules out a $\mathrm{Cw}$ climate (X3.wet and X3.dry are closely correlated to $P_{\text {dry }} /$ wet $)$. In conjunction with the Köppen signature results ruling out summer-dry conditions, the CLAMP precipitation and temperature estimates point towards cold subtropical to mild temperate $\mathrm{Cfa}$ climates at the margin to fully temperate $\mathrm{Cfb}$ climates.

\subsection{Comparison to palaeoclimate and palaeoenvironment inferences from other proxies}

A further refinement of previous climate and vegetation inferences can be made regarding the distinction between tropical $\left(T_{\min } \equiv \mathrm{CMMT} \geq 18^{\circ} \mathrm{C}\right)$, subtropical $(8-12$ months with $T \geq 10^{\circ} \mathrm{C}$; $\sim$ MAT $12-18^{\circ} \mathrm{C}$, and CMMT $<18^{\circ} \mathrm{C}$ ), and temperate climates. CLAMP consistently resolves MAT < $18^{\circ} \mathrm{C}$ and $\mathrm{CMMT}<6^{\circ} \mathrm{C}$ for the localities Eskihisar and Tinaz, and this agrees with the results from Köppen signatures and a previous qualitative assessment of palaeoenvironments in the Yatağan Basin (Güner et al., 2017). Both these results, strongly rejecting seasonal $\mathrm{Cw}$ climates, summerdry Cs, and tropical A climates (at least for non-coastal areas) for the middle Miocene of western Anatolia, have implications for the reconstruction of palaeoenvironments of famous vertebrate localities in Anatolia that are assigned to MN6. The $\delta^{13} \mathrm{C}$ composition from fossil tooth enamel at Paşalar, western Anatolia, MN6, indicates that animals were feeding on $C_{3}$ vegetation (Quade and Cerling, 1995). The palaeoenvironment for this locality was determined as closer to Indian subtropical forests, with seasonal summer rainfalls (i.e. warm Cwa climates), semi-deciduous forest, and dense ground vegetation (Stringer and Andrews, 2011; Mayda et al., 2015). Using carnivore guild structures, Morlo et al. (2010) inferred open (Serengeti type, Aw climate) landscapes for the Central Anatolian MN6 vertebrate locality Çandır. Also, the NOW database (http://www.helsinki.fi/ science/now/, last access: 13 September 2018; The NOW Community, 2018) refers to Çandır as more open ("woodland biome", "open vegetation structure", "grassland with mosaic of forests") and to Paşalar as more forested landscapes ("subtropical", "closed vegetation structure", "semideciduous forests"). Bernor et al. (1979) using the community structure of vertebrate fauna inferred densely wooded environments for Çandır. In a later study based on a taxonomic revision of carnivores, Mayda et al. (2015) proposed a mixed environment between tropical forests and open savannah landscapes for Çandır. It is important to note that these carnivore guild structure studies used only two modern calibration faunas to estimate palaeoenvironments: one tropical rainforest fauna in Guyana and one savannah (tropical) fauna in the Serengeti (Morlo et al., 2010). Thus, using this proxy, only two environments can be reconstructed: tropical savannah or rainforest.

Our plant-proxy-based climate reconstruction unambiguously rejects a tropical climate for the middle Miocene Yatağan Basin, and major biogeographic patterns strongly suggest northern hemispheric affinities. Similar environmental conditions as reconstructed in our study have been inferred for most of western Anatolia during the late early and middle Miocene (Kayseri-Özer, 2017). Most proxies currently used to infer climate and vegetation in western Anatolia during the middle Miocene (carnivore guild structures, vertebrate community structure, plant functional types, plant macrofossils, pollen and spores; Mayda et al., 2015, 2016; Kayseri-Özer, 2017; Güner et al., 2017; Bouchal et al., 2016, 2017; Bouchal, 2018) clearly infer forested vegetation with varying contributions of open vegetation. In contrast, Strömberg et al. (2007) found that "all Miocene phytolith assemblages point to relatively open vegetation, such as savanna or open woodland dominated by open-habitat grasses, or a mixture of grassland and wooded areas". This result may be biased (see Jokela, 2015, p. 44) and increased diversity of grass types in the phytolith record may not necessarily indicate the presence of widespread open, grass-dominated landscapes. 


\subsection{Modern climate analogues}

The inferred climate for the middle Miocene Yatağan Basin plant assemblages is characterized by a MAT of $11-15^{\circ} \mathrm{C}$, coldest-month mean temperature (CMMT) of $0-6^{\circ} \mathrm{C}$, MAP of ca. 1000-2000 mm, and ratios of X3.wet/X3.dry of 2.93.8. A non-exhaustive search for climate stations with this combination of climate parameters (Supplement S7) identified a single closest match: Pacific central Honshu in Japan. X3.wet/X3.dry ratios and MAT are similar to the upper limits of the ranges reconstructed for the middle Miocene Yatağan Basin. East Asian Cf climates are generally characterized by distinct summer rain maxima. The modern vegetation of Japan is home to many plant taxa that are currently absent from western Eurasia but were abundant in Neogene plant assemblages of western Eurasia (e.g. Cephalotaxus, Cryptomeria, Torreya, Alangium, Camellia, Castanopsis, Cercidiphyllum, Daphniphyllum, Eurya, Fatsia; Mai, 1995; Miyawaki, 1984; see also Milne, 2004). These taxa require warm and humid equable climates.

A further close match is the area from northern Turkey via Georgia to northern Iran: the Euxinian-Hyrcanian region (Supplement S7). Climates at the transition between $\mathrm{Csa}$ and $\mathrm{Cfa} / \mathrm{b}$ of the region north of Istanbul have up to $1166 \mathrm{~mm}$ MAP (Ustaoğlu, 2012) and other climate parameters in this area match the Miocene climate of southwestern Turkey inferred by CLAMP. Towards the humid northeastern part of Turkey, X3.wet/X3.dry ratios are lower (2.4 for Rize, Hopa, and P'ot'i and K'obulet'i in adjacent western Georgia). Further to the east, south of the Caspian Sea, Rasht and Kiashahr have Cfa and borderline Csa to Cfa climates with slightly more pronounced seasonality than the reconstructed climate for the Miocene of southwestern Turkey (X3.wet/X3.dry ratios of 4.4 and 4.2). In contrast, $\mathrm{X} 3$.wet/X3.dry ratios in modern Mediterranean western and southwestern Turkey amount to 25 (Izmir) and 21.8 (Muğla, Yatağan Basin). It is noteworthy that modern Cf climates of the Euxinian-Hyrcanian region differ markedly from those of the Pacific part of Honshu by their summer minima in rainfall (Supplement S7). This feature indicates a (weak) Mediterranean influence in this region. According to Biltekin et al. (2015), the Anatolian refugium emerged after the retreat of the Paratethys Sea in the Pliocene and increasing monsoon influence (increased summer rainfall) over the northeastern Mediterranean region (the latter accounting for the much higher summer precipitation in the EuxinianHyrcanian than in the Mediterranean region). The Mediterranean climate type in Europe appeared first during the late Pliocene and early Pleistocene (ca. 3.2-2.3 Ma; Suc, 1984) coinciding with first large-scale north hemispheric glaciation in the North Atlantic (Denk et al., 2011).

\subsection{Detection of Miocene global climatic changes in the terrestrial fossil record}

High-resolution benthic stable isotopic data provide a detailed chronology of (global) climatic changes across the $\mathrm{MCO}$, the MMCT, and the subsequent more pronounced cooling (Holbourn et al., 2014). The terrestrial record usually does not provide the same temporal resolution but allows focussing on regional patterns. The transition from MCO to MMCT has previously been documented in high-resolution palynological analyses. For example, Jiménez-Moreno et al. (2005) investigated a core from the Pannonian Basin and observed a decline in megathermic taxa at the transition from MCO to MMCT. Also, Ivanov and Worobiec (2017) reported a decrease in thermophile taxa for the transition for Bulgaria and Poland. In southwestern Anatolia, Kayseri-Özer et al. (2014) investigated three localities in the Muğla-Ören area south of the Yatağan Basin, which are dated by vertebrate fossils as early and late MN5 and thus correspond to the MCO. These authors report a few warmth-loving elements (palms, Avicennia) that are missing in the younger strata of the Yatağan Basin. This could be due to the deltaic setting of these types of flora as opposed to the intramontane setting of the Yatağan Basin flora. In general, the flora of the Muğla-Ören area is very similar to the flora of the Yatağan Basin (Bouchal et al., 2017). However, a striking difference to the MN6 and MN7 + 8 assemblages of the Yatağan Basin is the almost entire absence of herbaceous taxa (non-arboreal pollen) in the MN5 assemblages of Ören (see Figs. 7-9 in Kayseri-Özer et al., 2014). This may indicate the presence of more closed forest vegetation of the laurisilva type. The extant laurisilva or laurel forest is a type of subtropical forest found in areas with high humidity and relatively stable, mild temperatures. The assemblages of the Yatağan Basin, show fluctuating arboreal to non-arboreal pollen (AP : NAP) ratios with a peak in NAP in the transition zone MN6 to MN7 + 8 (pollen zone PZ 2-3). This peak could possibly correspond to a sharp cooling detected in the benthic stable isotopic data at 13.9-13.8 Ma (Holbourn et al., 2014). In the European mammal stratigraphy (Neubauer et al., 2015), the boundary MN6 to MN7 +8 is at $13.9 \mathrm{Ma}$. Above PZ 2-3, the radiometrically dated Yeni Eskihisar pollen assemblage clearly belongs to MN7 +8 . Here, and in the nearby locality Çatakbağyaka woody taxa (including some warmth-loving taxa) are again more prominent. Thus, although the correlation of pollen zones $2-3$ with the cooling event at $13.9-13.8 \mathrm{Ma}$ is highly speculative, it is clear that the MCO in southwestern Anatolia was characterized by laurisilva vegetation with little contribution of herbaceous taxa. During the MMCT the main woody taxa did not change much, but herbaceous taxa played a much greater role. This indicates higher structural complexity of the vegetation. The presence of early hominids in western Anatolia during this time might be connected to this more complex vegetation. It is unclear at present, whether these changes were accompanied by changes in concentra- 
tions of atmospheric $\mathrm{CO}_{2}$. The compilation of reconstructed $\mathrm{CO}_{2}$ values across the Cenozoic from hundreds of proxy data (Beerling and Royer, 2011) shows that there is no agreement between different proxies for the MCO and the subsequent middle Miocene climate cooling. Phytoplankton stable isotopic data suggest nearly stable $\mathrm{CO}_{2}$ concentrations (MCO, 227-327 ppm; MMCT, 265-300 ppm; see Table S1 of Beerling and Royer, 2011). In contrast, stomata densities from fossil leaves suggest a pronounced decline in $\mathrm{CO}_{2}$ across this interval.

\section{Conclusion}

Here we used three proxies to infer climate, palaeoenvironments, and biogeographic affinities of middle Miocene floras of southwestern Anatolia. We showed that the palaeobotanical record resolves transitions from the warm MCO (16.8$14.7 \mathrm{Ma})$ to the MMCT (14.7-13.9 Ma) and a more pronounced cooling at 13.9-13.8 Ma, mainly expressed in the changing and fluctuating ratios between AP and NAP taxa. Using threshold percentages for main tree taxa, we further show that although NAP values significantly increased during the MMCT, AP taxa remained relatively abundant, signifying the coexistence of forested and open landscapes during this transition. In addition, the biogeographic analysis indicates mainly northern hemispheric biogeographic affinities of the middle Miocene flora of southwestern Anatolia and thus invalidates previous comparisons with tropical environments. Tropical climate conditions are also rejected by the Köppen signatures of the investigated flora and by the CLAMP analysis. Finally, the CLAMP data readily distinguish between strongly seasonal $\mathrm{Cs}$ and $\mathrm{Cw}$ and fully humid Cf climate types. More combined macrofossil and microfossil studies are needed for the Neogene of Turkey in order to establish a robust framework of terrestrial climate evolution in this important region.

Data availability. All data used in this article are available in the Supplement and in Bouchal et al. (2018).

Supplement. The supplement related to this article is available online at: https://doi.org/10.5194/cp-14-1427-2018-supplement.

Author contributions. JMB and TD designed the study. TD wrote the first draft of the paper. THG made the CLAMP analysis, JMB made the Köppen signature analysis. All authors discussed the data and contributed to the final version of the paper.

Competing interests. The authors declare that they have no conflict of interest.
Acknowledgements. This work was supported by the Swedish research council (grant no. 2015-03986 to Thomas Denk). We thank Guido W. Grimm for his comments on the first version of the paper. Valuable suggestions by the reviewers Lydie M. Dupont and Jean-Pierre Suc are highly appreciated.

Edited by: Zhengtang Guo

Reviewed by: Jean-Pierre Suc and Lydie Dupont

\section{References}

Ackerly, D. D.: Adaptation, niche conservatism, and convergence: comparative studies of leaf evolution in the California chaparral, Am. Nat., 163, 654-671, 2004.

Aiglstorfer, M., Mayda, S., and Heizmann, E. P. J.: First record of if late Miocene Moschidae from Turkey: Micromeryx and Hispanomeryx from Catakağyaka (Muğla, SW Turkey), Comptes Rendus Palevol., 17, 178-188, 2018.

Alçiçek, H.: Stratigraphic correlation of the Neogene basins in southwestern Anatolia: Regional palaeogeographical, palaeoclimatic and tectonic implications, Palaeogeogr. Palaeocl., 291, 297-318, 2010.

Andrews, P. and Tobien, H.: New Miocene locality in Turkey with evidence on the origin of Ramapithecus and Sivapithecus, Nature, 268, 699-701, 1977.

Atalay, Z.: Muğla-Yatağan ve yakın dolayıkarasal Neojen'inin stratigrafi araştırması, Bull. Geol. Soc. Turkey, C23, 93-99, 1980.

Becker-Platen, J. D.: Lithostratigraphische Untersuchungen im Känozoikum Südwest-Anatoliens (Türkei) (Känozoikum und Braunkohlender der Türkei, 2), Beih. Geol. Jb., 97, 1-244, 1970.

Becker-Platen, J. D., Benda, L., and Steffens, F.: Litho- und biostratigraphische Deutung radiometrischer Altersbestimmungen aus dem Jungtertiär der Türkei, Geol. Jb., B25, 139-167, 1977.

Beerling, D. J. and Royer, D. L.: Convergent Cenozoic $\mathrm{CO}_{2}$ history, Nat. Geosci., 4, 418-420, 2011.

Bernor, R. L., Andrews, P. J., Solounias, N., and Van Couvering, J. A. H.: The evolution of "Pontian" mammal faunas: some zoogeographic, palaeoecologic and chronostratigraphic considerations. Annales Géologiques des Pays Helléniques, Tome hors série [special issue], 1979, 81-89, 1979.

Biltekin, D., Popescu, S.-M., Suc, J.-P., Quézel, P., JiménezMoreno, G., Yavuz-Işık, N., and Çağatay, M. N.: Anatolia: A long-time plant refuge area documented by pollen records over the last 23 million years, Rev. Palaeobot. Palynol., 215, 1-22, 2015.

Bouchal, J. M.: The middle Miocene palynofloras of the Salihpaşalar lignite mine (Yatağan Basin, southwest Anatolia): environmental characterisation and comparison with coeval palynofloras from adjacent subbasins, Palaeobio. Palaeoen., in press, 1-46, https://doi.org/10.1007/s12549-018-0345-0, 2018.

Bouchal, J. M., Zetter, R., Grímsson, F., and Denk, T.: The middle Miocene palynoflora and palaeoenvironments of Eskihisar (Yatağan Basin, southwestern Anatolia): a combined LM and SEM investigation, Bot. J. Linn. Soc., 182, 14-79, 2016.

Bouchal, J. M., Mayda, S., Grímsson, F., Akgün, F., Zetter, R., and Denk, T.: Miocene palynofloras of the Tinaz lignite mine, Muğla, southwest Anatolia: taxonomy, palaeoecology and local vegetation change, Rev. Palaeobot. Palynol., 243, 1-36, 2017. 
Bouchal, J. M., Güner, T. H., and Denk, T.: SI1-7.zip. figshare. Dataset, https://doi.org/10.6084/m9.figshare.7122506, 2018.

Cohen, K. M., Finney, S. C., Gibbard, P. L., and Fan, J.-X.: The ICS International Chronostratigraphic Chart, available at: http:// www.stratigraphy.org/index.php/ics-chart-timescale (last access: 13 September 2018), Episodes, 36, 199-204, 2013 (updated 2017).

Corbett, S. L. and Manchester, S. R.: Phytogeography and fossil history of Ailanthus (Simaroubaceae), Int. J. Plant Sci., 165, 671690, 2004

Denk, T., Grímsson, F., Zetter, R., and Símonarson, L. A.: Late Cainozoic Floras of Iceland: 15 Million Years of Vegetation and Climate History in the Northern North Atlantic, Springer, Heidelberg, New York, 2011.

Denk, T., Grimm, G. W., Grímsson, F., and Zetter, R.: Evidence from "Köppen signatures" of fossil plant assemblages for effective heat transport of Gulf Stream to subarctic North Atlantic during Miocene cooling, Biogeosciences, 10, 7927-7942, https://doi.org/10.5194/bg-10-7927-2013, 2013.

Denk, T., Velitzelos, D., Güner, H. T., and Ferrufino-Acosta, L.: Smilax (Smilacaceae) from the Miocene of western Eurasia with Caribbean biogeographic affinities, Am. J. Bot., 102, 423-438, 2015.

Denk, T., Velitzelos, D., Güner, H. T., Bouchal, J. M., Grímsson, F., and Grimm, G. W.: Taxonomy and palaeoecology of two widespread western Eurasian Neogene sclerophyllous oak species: Quercus drymeja Unger and Q. mediterranea Unger, Rev. Palaeobot. Palynol., 241, 98-128, 2017.

Favre, E., Escarguel. G., Suc, J.-P., Vidal. G., and Thévenod, L.: A contribution to deciphering the meaning of AP/NAP with respect to vegetation cover, Rev. Palaeobot. Palynol., 148, 13-35, 2008.

Flower, B. P. and Kennett, J. P.: Middle Miocene deepwater paleoceanography in the southwest Pacific: relations with East Antarctic Ice Sheet development, Paleoceanography, 10, 1095-1112, 1995.

Geraads, D., Begun, D., and Güleç, E.: The middle Miocene hominoid site of Çandir, Turkey: general palaeoecological conclusions from the mammalian fauna, Courier Forschungs-Institut Senckenberg, 240, 241-250, 2003.

Grimm, G. W. and Potts, A. J.: Fallacies and fantasies: the theoretical underpinnings of the Coexistence Approach for palaeoclimate reconstruction, Clim. Past, 12, 611-622, https://doi.org/10.5194/cp-12-611-2016, 2016.

Güner, H. T., Bouchal, J. M., Köse, N., Göktaş, F., Mayda, S., and Denk, T.: Landscape heterogeneity in the Yatağan Basin (southwestern Turkey) during the middle Miocene inferred from plant macrofossils, Palaeontogr. B, 296, 113-171, 2017.

Holbourn, A., Kuhnt, W., Lyle, M., Schneider, L., Romero, O., and Andersen, N.: Middle Miocene climate cooling linked to intensification of eastern equatorial Pacific upwelling, Geology, 42, 19-22, 2014.

Ivanov, D. and Worobiec, E.: Middle Miocene (Badenian) vegetation and climate dynamics in Bulgaria and Poland based on pollen data, Palaeogeogr. Palaeocl., 467, 83-94, 2017.

Jia, L.-B., Manchester, S. R., Su, T., Xing, Y.-W., Chen, W.-Y., Huang, Y.-J., and Zhou, Z.-K.: First occurrence of Cedrelospermum (Ulmaceae) in Asia and its biogeographic implications, J. Plant Res., 128, 747-761, 2015.
Jiménez-Moreno, G.: Utilización del análisis polínico para la reconstrucción de la vegetación, clima y estimación de paleoaltitudes a lo largo de arco alpino europeo durante el Mioceno (21-8 Ma), PhD Thesis University Granada, Granada, 313 pp., 2005.

Jiménez-Moreno, G., Rodríguez-Tovar, F.-J., Pardo-Igúzquiza, E., Fauquette, S., Suc, J.-P., and Müller, P.: High-resolution palynological analysis in late early-middle Miocene core from the Pannonian Basin, Hungary: climatic changes, astronomical forcing and eustatic fluctuations in the Central Paratethys, Palaeogeogr. Palaeocl., 216, 73-97, 2005.

Jokela, T.: The high, the sharp and the rounded: paleodiet and paleoecology of Late Miocene herbivorous mammals from Greece and Iran, $\mathrm{PhD}$ thesis, University of Helsinki, available at: http: //urn.fi/URN:NBN:fi-fe2017112252491 (last access: 13 September 2018), 2015.

Kayseri-Özer, M. S.: Cenozoic vegetation and climate change in Anatolia - A study based on the IPR-vegetation analysis, Palaeogeogr. Palaeocl., 467, 37-68, 2017.

Kayseri-Özer, M. S., Akgün, F., Mayda, S., and Kaya, T.: Palynofloras and vertebrates from Muğla-Ören region (SW Turkey) and palaeoclimate of the Middle Burdigalian-Langhian period in Turkey, Bull. Geosci., 89, 137-162, 2014.

Kottek, M., Grieser, J., Beck, C., Rudolf, B., and Rubel, F.: World map of the Köppen-Geiger climate classification updated, Meteorol. Z., 15, 259-263, 2006.

Kovar-Eder, J., Jechorek, H., Kvaček, Z., and Parashiv, V.: The Integrated Plant Record: An essential tool for reconstructing Neogene zonal vegetation in Europe, Palaios, 23, 97-111, 2008.

Kvaček, Z.: Do extant nearest relatives of thermophile European Cenozoic plant elements reliably reflect climatic signal?, Palaeogeogr. Palaeocl., 253, 32-40, 2007.

Lisitsyna, O. V., Giesecke, T., and Hicks, S.: Exploring pollen percentage threshold values as an indication for the regional presence of major European trees, Rev. Palaeobot. Palynol., 166, 311-324, 2011.

Magri, D., Di Rita, F., Aranbarri, J., Fletcher, W., and GonzálezSampériz, P.: Quaternary disappearance of tree taxa from Southern Europe: Timing and trends, Quat. Sci. Rev., 163, 23-55, 2017.

Mai, D. H.: Tertiäre Vegetationsgeschichte Europas, Gustav Fischer Verlag, Jena, 1995.

Martinetto, E.: The role of central Italy as a centre of refuge for thermophilous plants in the late Cenozoic, Acta Palaeobot., 41, 299-319, 2001.

Mayda, S., Koufos, G. D., Kaya, T., and Gul, A.: New carnivore material from the Middle Miocene of Turkey. Implications on biochronology and palaeoecology, Geobios, 48, 9-23, 2015.

Mayda, S., Kaya, T., and Aiglstorfer, T. M.: Revisiting the middle Miocene (MN7/8) fauna of Catakağyaka (Mugla, SW Turkey), in: Taking the orient express, RCMNS Workshop on the role of Anatolia in Mediterranean Neogene Palaeobiogeography, Izmir, 16-18 September 2016.

Milne, R. I.: Phylogeny and biogeography of Rhododendron subsection Pontica, a group with a tertiary relict distribution, Mol. Phylogenet. Evol., 33, 389-401, 2004.

Miyawaki, A.: A vegetation-ecological view of the Japanese archipelago, Bulletin of the Institute of Environmental Science and Technology, 11, 85-101, 1984. 
Morlo, M., Gunnell, G. F., and Nagel, D.: Ecomorphological analysis of carnivore guilds in the Eocene through Miocene of Laurasia, in: Carnivoran Evolution: New Views on Phylogeny, Form, and Function, edited by: Goswami, A. and Friscia, A., Cambridge University Press, Cambridge, UK, 2010.

Neubauer, T. A., Georgopoulou, E., Kroh, A., Harzhauser, M., Mandic, O., and Esu, D.: Synopsis of European Neogene freshwater gastropod localities: updated stratigraphy and geography, Palaeontogia Electronica, 18.1.3T, 1-7, 2015.

New, M., Hulme, M., and Jones, P.: Representing TwentiethCentury Space-Time Climate Variability. Part I: Development of a 1961-90 Mean Monthly Terrestrial Climatology, J. Climate, 12, 829-856, 1999.

New, M., Lister, D., Hulme, M., and Makin, I.: A high-resolution data set of surface climate over global land areas, Climate Res., 21, 1-15, 2002.

Peel, M. C., Finlayson, B. L., and McMahon, T. A.: Updated world map of the Köppen-Geiger climate classification, Hydrol. Earth Syst. Sci., 11, 1633-1644, https://doi.org/10.5194/hess-11-16332007, 2007.

Quade, J. and Cerling, T. E.: Expansion of C4 grasses in the Late Miocene of Northern Pakistan: evidence from stable isotope paleosols, Palaeogeogr. Palaeocl., 115, 91-116, 1995.

Rubel, F., Brugger, K., Haslinger, K., and Auer, I.: The climate of the European Alps: Shift of very high resolution KöppenGeiger climate zones 1800-2100, Meteorol. Z., 26, 115-125, https://doi.org/10.1127/metz/2016/0816, 2017.

Shevenell, A. E., Kennett, J. P., and Lea, D. W.: Middle Miocene Southern Ocean cooling and Antarctic cryosphere expansion, Science, 305, 1766-1770, 2004.

Spicer, R. A.: CLAMP, in: Encyclopedia of Paleoclimatology and Ancient Environments, edited by: Gornitz, V., Springer, Dordrecht, 2008.
Stringer, C. and Andrews, P.: The Complete World of Human Evolution, Thames \& Hudson, London, 2011.

Strömberg, C. A. E., Werdelin, L., Friis, E. M., and Saraç, G.: The spread of grass-dominated habitats in Turkey and surrounding areas during the Cenozoic: phytolith evidence, Palaeogeogr., Palaeocl., 250, 18-49, 2007.

Suc, J.-P.: Origin and evolution of the Mediterranean vegetation and climate in Europe, Nature, 307, 429-432, 1984.

Ter Braak, C. J. F.: Canonical correspondence Analysis: a new eigenvector technique for multivariate direct gradient analysis, Ecology, 67, 1167-1179, 1986.

The NOW Community.: New and old worlds database of fossil mammals (NOW), Licensed under CC BZ 4.0 Release 2008, available at: http://www.helsinki.fi/science/now/, last access: 23 April 2018.

Ustaoğlu, B.: Comparisons of annual meanprecipitation gridded and station data: An example from Istanbul, Turkey, Marmara Coğrafya Dergisi, 26, 71-81, 2012.

Wang, Q., Dilcher, D. L., and Lott, T. A.: Podocarpium A. Braun ex Stizenberger 1851 from the middle Miocene of Eastern China, and its palaeoecology and biogeography, Acta Palaeobot., 47, 237-251, 2007.

Yang, J., Spicer, R. A., Spicer, T. E. V., and Li, C.-S.: 'CLAMP Online': a new web-based palaeoclimate tool and its application to the terrestrial Paleogene and Neogene of North America, Palaeobio. Palaeoen., 91, 163-183, 2011.

Yavuz-Işık, N., Saraç, G., Ünay, E., and de Bruijn, H.: Palynological analysis of Neogene mammal sites of Turkey - Vegetational and climatic implications, Yerbilimeri, 32, 105-120, 2011. 